\title{
Bacteremia caused by Bergeyella zoohelcum in an infective endocarditis patient: case report and review of literature
}

\author{
Yili Chen ${ }^{\dagger}$, Kang Liao ${ }^{\dagger}$, Lu Ai, Penghao Guo, Han Huang, Zhongwen Wu and Min Liu
}

\begin{abstract}
Background: Bergeyella zoohelcum is an aerobic, Gram-negative bacterium that is frequently isolated from the upper respiratory tract of dogs, cats and other mammals. Clinically, B. zoohelcum has been reported causing cellulitis, tenosynovitis, leg abscess and septicemia, which is closely connected with animal bites. Here we describe a case of bacteremia in an infective endocarditis (IE) patient caused by B. zoohelcum, in China.

Case presentation: A 27-year-old infective endocarditis woman who had no history of dog bite nor other mammal exposure suffered bacteremia caused by B. zoohelcum. This patient, without evidence of polymicrobial infection, was treated with cefuroxime and had a good outcome.

Conclusions: B. zoolhelcum bacteremia is rarely reported in IE patients. Our report expands the range of known bacterial causes of infective endocarditis.
\end{abstract}

Keywords: Bergeyella zoohelcum, Bacteremia, Infective endocarditis

\section{Background}

Bergeyella (formerly Weeksella) zoohelcum is an aerobic, rod-shaped, Gram-negative, non-motile, non-saccharolytic bacterium which is usually isolated from the upper respiratory tract of dogs, cats and other mammals [1-3]. Most reported cases of human infection by these bacteria are due to animal bites or are associated with prolonged exposure to pets [4-7]. Additionally, it is reported that a patient suffered B. zoohelcum bacteremia after eating the food prepared with coagulated goat blood [8]. A tsunami victim with cellulitis due to $B$. zoohelcum has been reported as well [9]. Here, we report a case of bacteremia caused by $B$. zoohelcum in an infective endocarditis patient and review of literature.

\section{Case presentation}

A 27-year-old Chinese woman was admitted to hospital (The First Affiliated Hospital of Sun Yat-sen University, Guangzhou, China) due to repeated fever for 3 months, chest distress, tachypnea, and palpitation for a month.

\footnotetext{
* Correspondence: nancy20151031@163.com

${ }^{\dagger}$ Equal contributors

Department of Laboratory Medicine, The First Affiliated Hospital of Sun Yat-sen University, Guangzhou, Guangdong 510080, China
}

The patient has been in her usual state of health before admission. Because of tonsillitis, she got fever and sore throat. She slightly improved after symptomatic treatment but suffered a relapse several days later, with maximum body temperature at $40.3{ }^{\circ} \mathrm{C}$. A detailed history disclosed that the patient did not keep any pets, smoke, drink alcohol, or use illicit drugs. She denied sustaining any dog or cat bites, either. She did not have any recent travel history, either within or outside of China. Moreover, she did not visit farms or any markets with live animals, denying any other potential environmental exposures.

On examination, she had a tympanic temperature of $38.2{ }^{\circ} \mathrm{C}$, blood pressure of $105 / 43 \mathrm{mmHg}$, pulse rate of $103 / \mathrm{min}$ and respiratory rate of $20 / \mathrm{min}$. Physical examination revealed that $2 / 6$ level systolic murmur was audible at the mitral area, and diastolic murmur was at aortic area. Ultrasonic cardiogram revealed infective endocarditis that the formation of vegetations on the mitral valve with severe mitral insufficiency, aortic valve vegetations with severe aortic insufficiency, and prolapse of anterior tricuspid valve leaflet with moderate tricuspid insufficiency. Laboratory evaluation revealed leukocyte count of $6740 / \mathrm{mm} 3$ with $65.5 \%$ neutrophils and $23.5 \%$ 
band forms, erythrocyte sedimentation rate of $120 \mathrm{~mm} /$ $\mathrm{h}$ (normal range, $0-20 \mathrm{~mm} / \mathrm{h}$ ), C-reactive protein of $89 \mathrm{mg} / \mathrm{L}$ (normal range, $<1 \mathrm{mg} / \mathrm{L}$ ), brain natriuretic peptide of $702.1 \mathrm{pg} / \mathrm{ml}$ (normal range, $0-84.0 \mathrm{pg} / \mathrm{ml}$ ), and microscopic hematuria.

Blood cultures were obtained on admission day and empiric antibiotic treatment with intravenous drip of cefuroxime $1.5 \mathrm{~g}$ every $8 \mathrm{~h}$ was started. Both sets of blood cultures were positive after 2 days and isolated a Gram negative rod-shaped bacteria. The organism tested positive for oxidase, catalase, urea and indole; while PYR and DNAase test were negative. Initially, the isolate was misidentified as Brevundimonas diminuta by Vitek 2 system with only $87.6 \%$ identity (bioMérieux SA, Marcy, France). To confirm the identity of the isolate, a fragment of the 16S rRNA gene was amplified using primer sets 16S-forward (5' - AGA GTT TGA TCC TGG CTC AG-3') and 16S-reverse (5'- ACG GCT ACC TTG TTA CGA CTT-3') by the polymerase chain reaction [10] and the resultant polymerase chain reaction product sequenced. The sequencing data were queried against the GenBank 16S rRNA gene database. The best match returned was the Bergeyella zoohelcum, ATCC 43767 type strain, with $98.2 \%$ identity, whereas the next best match was the Riemerella anatipestifer, ATCC 11845 strain, with only $91.2 \%$ identity. Although, according to the identity algorithm of the CLSI guideline MM18-A about glucose non-fermenting Gram negative bacilli [11], the $98.2 \%$ identity of this Bergeyella zoohelcum strain was a bit lower than the requirement of $\geq 99.0 \%$ identity (With $>0.8 \%$ separation from most closely related species); taken together, the biological characteristics and 16S rRNA gene sequencing data strongly supported the identification of B. zoohelcum.

The antibiotic susceptibility of the Bergeyella zoohelcum strain was determined by the Kirby-Bauer disk diffusion method on Mueller-Hinton agar plates with $5 \%$ horse blood with use of Oxoid disks (Oxoid Ltd., Basingstoke, Hants, RG24 8PW, UK). Although there are no categorical interpretative criteria for antimicrobial susceptibility testing (AST) data for B. zoohelcum, the isolate exhibited large inhibition zone (millimeter) for all antimicrobials tested: ampicillin $40 \mathrm{~mm}$, cefixoxime $42 \mathrm{~mm}$, ceftriaxone $38 \mathrm{~mm}$, meropenem $40 \mathrm{~mm}$, erythromycin $26 \mathrm{~mm}$, clindamycin $28 \mathrm{~mm}$, trimethoprim/sulfamethoxazole $40 \mathrm{~mm}$, gentamicin $26 \mathrm{~mm}$, levofloxacin $28 \mathrm{~mm}$, which suggested the B. zoohelcum isolate was susceptible to $\beta$-lactams and fluoroquinolones. Moreover, the isolate presented negative for the production of $\beta$-lactamase according to the cefinase disk assay (bioMérieux SA, Marcy, France).

On day 3, the patient showed improvement of the clinical symptoms of fever, chest distress, and tachypnea. On day 10, the patient underwent combination of mitral and aortic valve bioprosthesis replacement, and tricuspid valvoplasty. However, tissue cultures taken from the surgical specimens did not produce notable bacterial growth. The patient completed a 6-week course of treatment with cefuroxime. She was discharged from the hospital in a stable condition and resumed her normal daily activities.

\section{Discussion}

B. zoohelcum, formerly belonging to Weeksella zoohelcum, is a nonfermentative Gram-negative rod which is a member of the family Flavobacteriaceae [12, 13]. It grows well on blood agar; while most strains do not grow on MacConkey's agar. Colonies are entire, circular, semitransparent, smooth, glossy, butyrous and very sticky, making them hard to remove from solid media. In broth, growth is weak. The colonies show no hemolysis on blood agar plates, while greening occasionally exists around colonies [14].The organisms show positive for oxidase, catalase and indole test, negative for PYR, resistant to colistin, and are non-pigmented [15].

Some strains of B. zoohelcum showed fastidious which only grew on chocolate agar and biochemically inactive, thus, preventing them from recovery and identification [8]. Therefore, in this case, the B. zoohelcum isolate was misidentified as Brevundimonas diminuta by the Vitek 2 system, with only $87.6 \%$ identity initially. Similarly, in both of the infective endocarditis cases reported by Kyung Mok Sohn et al. [16], Vitek 2 automated system misidentified the pathogen as Brevundimonas spp. Brevundimonas spp., of which $16 \mathrm{~S}$ rRNA gene sequences indicated a similarity of $94.9 \%$ with Bergeyella zoohelcum, suggesting that they belonged to a new species of Bergeyella. Notably, it was reported by Jumi Yi et al. [10], that B. zoohelcum isolate could be identified by MALDITOF MS on the Bruker Biotyper platform (Bruker Daltonics, Billerica, MA) [ $\log$ (score) value $>2.0]$, due to its competency of detecting the species-specific biomarkers instead of an organism's metabolic activity for identification.

B. zoohelcum isolates are proved to be susceptible to penicillin, and resistant to colistin. However, these features are often used for identification rather than antimicrobial susceptibility testing [17]. Though there is no standard antimicrobial agent recommended for the treatment of $B$. zoohelcum infections, it shows highly susceptible to $\beta$-lactams and fluoroquinolones. Successful treatment with ampicillin/sulbactam [8], amoxicillin/clavulanic acid, cefazolin with gentamicin, cefuroxime, cefotaxime and ciprofloxacin has been reported $[5,6,8-10]$. In this case, the patient showed improvement of the clinical symptoms of fever, chest tightness, and tachypnea after 3 days of intravenous drip of cefuroxime $1.5 \mathrm{~g}$ every $8 \mathrm{~h}$. 
Table 1 Summary of reported cases of Bergeyella zoohelcum infection

\begin{tabular}{|c|c|c|c|c|c|c|}
\hline Reference & $\begin{array}{l}\text { Age } \\
(y r) / S e x\end{array}$ & Infection & Exposure & Underlying disease & Treatment & Outcome \\
\hline Noel et al., 1989 [18] & $80 / F$ & $\begin{array}{l}\text { Bed sore } \\
\text { infection }\end{array}$ & Cat contact & Diabetes mellitus & Cefotaxime & Recovered \\
\hline Montejo et al., 2001 [5] & $33 / \mathrm{M}$ & $\begin{array}{l}\text { Wound } \\
\text { infection }\end{array}$ & Dog bite & None & Day 1-14: amoxicillin-clavulanic & Recovered \\
\hline Kivinen et al., 2003 [19] & $77 / F$ & Skin infection & Cat contact & Diabetes mellitus, steriod use & Cefotaxime & Recovered \\
\hline Shukla SK et al., 2004 [7] & $60 / F$ & $\begin{array}{l}\text { Cellulitis and } \\
\text { lymphangitis }\end{array}$ & Cat bite & Not reported & $\begin{array}{l}\text { Day 1: Amoxicillin/clavulanate } \\
\text { Day 2-7: Ampicillin/sulbactam }\end{array}$ & Recovered \\
\hline Beltran et al., 2006 [8] & $44 / F$ & Diarrhea & $\begin{array}{l}\text { Goat's blood } \\
\text { ingestion }\end{array}$ & None & Day 2-9: ciprofloxacin & Recovered \\
\hline Wei-Ru lin et al., 2007 [15] & $73 / \mathrm{M}$ & Cellulitis & Dog contact & $\begin{array}{l}\text { Liver cirrhosis, transitional cell } \\
\text { carcinoma of urinary bladder }\end{array}$ & $\begin{array}{l}\text { Day 1-14: Cefazolin and } \\
\text { gentamicin }\end{array}$ & Recovered \\
\hline \multirow[t]{2}{*}{ Kyung Mok Sohn et al., 2015 [16] } & $26 / M$ & $\begin{array}{l}\text { Infective } \\
\text { endocarditis }\end{array}$ & None & None & $\begin{array}{l}\text { Day 4-5:ampicillin/sulbactam } \\
\text { Day 6-48:ceftriaxone }\end{array}$ & Recovered \\
\hline & $47 / \mathrm{M}$ & $\begin{array}{l}\text { Infective } \\
\text { endocarditis }\end{array}$ & None & $\begin{array}{l}\text { Paroxysmal supraventricular } \\
\text { tachycardia }\end{array}$ & $\begin{array}{l}\text { Day 1-3: ceftriaxone, ampicillin, } \\
\text { and gentamicin } \\
\text { Day 4-32: piperacillin/ } \\
\text { tazobactam and amikacin } \\
\text { Day33-36:ampicillin/sulbactam }\end{array}$ & Recovered \\
\hline This present case & $27 / F$ & $\begin{array}{l}\text { Infective } \\
\text { endocarditis }\end{array}$ & None & None & Day1-42:Cefuroxime & Recovered \\
\hline
\end{tabular}

B. zoohelcum has become an increasingly recognized cause of leg abscess, cellulitis, pneumonia, tenosynovitis, septicemia and meningitis, which is closely related to animal bites [7, 10, 15]. Moreover, worldwide, infective endocarditis caused by $B$. zoohelcum has been reported only in 2 cases ever [16] (Table 1). Although in the present case, the culture from the specimen of the mitral valve vegetation was negative, given that both sets of blood culture isolated B. zoohelcum, we assume, this is another rare report on IE caused by $B$. zoohelcum. Notably, most of the cases of Bergeyella zoohelcum bacteremia showed the presence of animal bites or mammals exposure (Table 1). B. zoolhelcum bacteremia has been previously reported in an 80-year-old diabetic woman who suffered from bed sores and had cat contact [18]. It has also been reported in a 33-year-old man after a dog bite over his left forearm [5]. Kivinen et al. reported that a 77-year-old patient presented with severe skin infection and B. zoolhelcum bacteremia after cat contact, who was in poor health taking steroidal and diabetic medication [19]. Beltran et al. reported that a 44-year-old woman got diarrhea and bacteremia, who consumed the food prepared with goat's blood [8].Wei$\mathrm{Ru}$ lin et al. reported another case of a man who developed B. zoolhelcum bacteremia with dog contact history [15]. But recently, Kyung Mok Sohn et al. reported a 26year-old male and a 47-year-old male who developed $B$. zoolhelcum bacteremia and infective endocarditis without any pets' exposure [16]. In the present case, the IE patient asserted that she had no history of dog bite nor other mammals exposure. Therefore, in this case, we assumed that dog bites, contact with a cat, or the ingestion of contaminated food may not be the only portal of entry for B. zoohelcum, but another unknown route of infection is subject to detection.

\section{Conclusions}

In conclusion, B. zoolhelcum bacteremia is rarely reported in IE patients. Our report expands the range of known bacterial causes of infective endocarditis. Since, traditional biochemical identification equipment may misidentify such organisms, MALDI-TOF MS and molecular assays will provide more accurate result on identification.

\section{Abbreviations Spectrometry \\ Acknowledgements \\ None. \\ Funding \\ None.}

B. zoohelcum: Bergeyella zoohelcum; IE: Infective endocarditis; MALDI-TOF MS: Matrix-Assisted Laser Desorption/Ionization Time of Flight Mass

Availability of data and materials

Data and materials of this report are publicly available.

\section{Authors' contributions}

YLC traced the case, was responsible for identifying the bacteria, and was a major contributor in writing the manuscript. $\mathrm{KL}$ interpreted the patient data regarding the infection disease. LA participated in the design and analyzing the sequence. $\mathrm{PHG}, \mathrm{HH}$ and $\mathrm{ZWW}$ participated in strain collection and literature searching. All authors read and approved the final manuscript. 


\section{Competing interest}

The authors declare that they have no competing interests.

\section{Consent for publication}

Written informed consent for publication of the clinical details including the medical history, bacteria cultures, pictures, videos and text was obtained from the patient.

\section{Ethics approval and consent to participate}

This report was approved by the Clinical Research and Ethics Committee of the First Affiliated Hospital of Sun Yat-sen University.

\section{Publisher's Note}

Springer Nature remains neutral with regard to jurisdictional claims in published maps and institutional affiliations.

Received: 31 December 2016 Accepted: 7 April 2017

Published online: 12 April 2017

\section{References}

1. Bailie WE, Stowe EC, Schmitt AM. Aerobic bacterial flora of oral and nasal fluids of canines with reference to bacteria associated with bites. J Clin Microbiol. 1978;7(2):223-31.

2. Talan DA, Citron DM, Abrahamian FM, Moran GJ, Goldstein EJ. Bacteriologic analysis of infected dog and cat bites. Emergency medicine animal bite infection study group. N Engl J Med. 1999;340(2):85-92.

3. Botha WC, Jooste PJ, Britz TJ. The taxonomic relationship of certain environmental flavobacteria to the genus Weeksella. J Appl Bacteriol. 1989;67(5):551-9.

4. Isotalo PA, Edgar D, Toye B. Polymicrobial tenosynovitis with Pasteurella multocida and other gram negative bacilli after a Siberian tiger bite. J Clin Pathol. 2000;53(11):871-2.

5. Montejo M, Aguirrebengoa K, Ugalde J, Lopez L, Saez NJ, Hernandez JL. Bergeyella zoohelcum bacteremia after a dog bite. Clin Infect Dis. 2001; 33(9):1608-9.

6. Reina J, Borrell N. Leg abscess caused by Weeksella zoohelcum following a dog bite. Clin Infect Dis. 1992;14(5):1162-3.

7. Shukla SK, Paustian DL, Stockwell PJ, Morey RE, Jordan JG, Levett PN, Frank $\mathrm{DN}$, Reed KD. Isolation of a fastidious Bergeyella species associated with cellulitis after a cat bite and a phylogenetic comparison with Bergeyella zoohelcum strains. J Clin Microbiol. 2004:42(1):290-3.

8. Beltran A, Bdiiwi S, Jani J, Recco RA, Go EE, Zaman MM. A case of Bergeyella zoohelcum bacteremia after ingestion of a dish prepared with goat blood. Clin Infect Dis. 2006;42(6):891-2.

9. Kallman O, Lundberg C, Wretlind B, Ortqvist A. Gram-negative bacteria from patients seeking medical advice in Stockholm after the tsunami catastrophe. Scand J Infect Dis. 2006;38(6-7):448-50

10. Yi J, Humphries R, Doerr L, Jerris RC, Westblade LF. Bergeyella zoohelcum associated with Abscess and Cellulitis after a dog bite. Pediatr Infect Dis J. 2016;35(2):214-6.

11. Clinical and Laboratory Standards Institute. Interpretive criteria for identification of bacteria and fungi by DNA target sequencing: approved guideline. MM18-a. Wayne: Clinical and Laboratory Standards Institute; 2008

12. Vandamme $P$, Segers $P$, Vancanneyt $M$, van Hove K, Mutters R, Hommez J, Dewhirst F, Paster B, Kersters K, Falsen E, et al. Ornithobacterium rhinotracheale gen. Nov., sp. nov., isolated from the avian respiratory tract. Int J Syst Bacteriol. 1994;44(1):24-37.

13. Holmes B, Steigerwalt AG, Weaver RE, Brenner DJ. Weeksella zoohelcum sp. nov. (formerly group Ilj) from human clinical specimens. Syst Appl Microbiol. 1986;8(3):191-6.

14. Saphir DA, Carter GR. Gingival flora of the dog with special reference to bacteria associated with bites. J Clin Microbiol. 1976;3(3):344-9.

15. Lin WR, Chen YS, Liu YC. Cellulitis and bacteremia caused by Bergeyella zoohelcum. J Formos Med Assoc. 2007;106(7):573-6.

16. Sohn KM, Huh K, Baek JY, Kim YS, Kang Cl, Peck KR, Lee NY, Song JH, Ko KS, Chung DR. A new causative bacteria of infective endocarditis, Bergeyella cardium sp. nov. Diagn Microbiol Infect Dis. 2015;81(3):213-6.

17. Vaneechoutte M, Dijkshoorn L, Nemec A, et al. Acinetobacter, Chryseobacterium, Moraxella, and other nonfermentative gram-negative rods. In: Versalovic J, Carroll KC, Jorgensen JH, et al., editors. Manual of clinical microbiology, vol. 1. 10th ed. Washington, DC: ASM Press; 2011. p. 714-38.

18. Noell F, Gorce MF, Garde C, Bizet C. Isolation of Weeksella zoohelcum in septicaemia. Lancet. 1989:2(8658):332.

19. Kivinen PK, Lahtinen MR, Ruotsalainen E, Harvima IT, Katila ML. Bergeyella zoohelcum septicaemia of a patient suffering from severe skin infection. Acta Derm Venereol. 2003;83(1):74-5.

\section{Submit your next manuscript to BioMed Central and we will help you at every step:}

- We accept pre-submission inquiries

- Our selector tool helps you to find the most relevant journal

- We provide round the clock customer support

- Convenient online submission

- Thorough peer review

- Inclusion in PubMed and all major indexing services

- Maximum visibility for your research

Submit your manuscript at www.biomedcentral.com/submit 